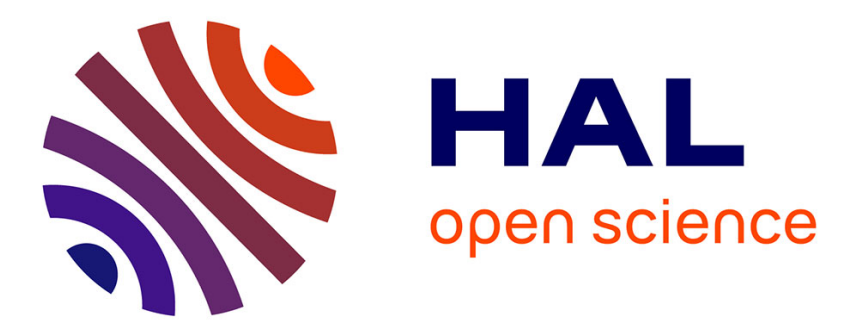

\title{
Annexin 1 is secreted in situ during ulcerative colitis in humans
}

Nathalie Vergnolle, Philippe Pagès, Rosine Guimbaud, Stanislas Chaussade, Lionel Bueno, Jean Escourrou, Christine Coméra

\section{- To cite this version:}

Nathalie Vergnolle, Philippe Pagès, Rosine Guimbaud, Stanislas Chaussade, Lionel Bueno, et al.. Annexin 1 is secreted in situ during ulcerative colitis in humans. Inflammatory Bowel Diseases, 2004, 10 (5), pp.584-592. hal-02677269

\section{HAL Id: hal-02677269 \\ https://hal.inrae.fr/hal-02677269}

Submitted on 31 May 2020

HAL is a multi-disciplinary open access archive for the deposit and dissemination of scientific research documents, whether they are published or not. The documents may come from teaching and research institutions in France or abroad, or from public or private research centers.
L'archive ouverte pluridisciplinaire HAL, est destinée au dépôt et à la diffusion de documents scientifiques de niveau recherche, publiés ou non, émanant des établissements d'enseignement et de recherche français ou étrangers, des laboratoires publics ou privés.

\section{다(1)(2)}

Distributed under a Creative Commons Attribution - ShareAlikel 4.0 International 


\title{
Annexin 1 Is Secreted in Situ During Ulcerative Colitis in Humans
}

\author{
Nathalie Vergnolle, PhD, *† Philippe Pagès, MD, $\neq$ Rosine Guimbaud, MD, PhD, $\S$ \\ Stanislas Chaussade, MD, PhD, § Lionel Buéno, PhD, * Jean Escourrou, MD, $\neq$ and \\ Christine Coméra, PhD*
}

\begin{abstract}
Although annexin 1 exerts extracellular anti-inflammatory properties, little is known about its release in inflammatory diseases. Here, we characterized annexin 1 secretion in ulcerative colitis (UC) patients. Annexin 1 was detected by immunoblotting, in tissue homogenates and supernatants of colonic biopsies incubated in culture media, and in luminal colonic perfusates of UC patients. Annexin 1 was released by inflamed colonic biopsies from patients having severe UC but not by biopsies from healthy colon of the same patient or by biopsies from non-UC patients or from patients with slight or moderate UC. Annexin 1 was detected in luminal colonic perfusates of patients having moderate or slight UC but not in perfusates from control patients. The level of annexin 1 expression and secretion was unrelated to long-term glucocorticoid treatment, but annexin 1 secretion in perfusates was induced, in some patients, by short-term glucocorticoid exposure. These results show that annexin 1 is secreted endogenously in the colon of patients with UC. This secretion, which occurs both in vitro and in vivo, depends on the severity of inflammation. Given the anti-inflammatory effects of annexin 1 , this protein may serve to down-regulate the inflammatory response in the course of inflammatory bowel disease.
\end{abstract}

Key Words: annexin 1, inflammation, ulcerative colitis

(Inflamm Bowel Dis 2004;10:584-592)

A nnexin 1 belongs to a family of homologous proteins that have the property to bind phospholipids in a calciumdependent manner. ${ }^{1}$ Several biological functions have been attributed to these proteins. Among them, annexin 1 was sug-

Received for publication June 3, 2003; accepted February 27, 2004.

From the *Laboratoire de Pharmacologie et Toxicologie, Institut National de la Recherche Agronomique, Toulouse, France; the $\dagger$ Department of Pharmacology and Therapeutics, University of Calgary, Cagary, Alberta, Canada; the $\$$ Service de Gastroentérologie, CHU Rangeuil, Toulouse, France; and the §Service d'Hépato-gastroentérologie, Hôpital Cochin, Paris, France.

N.V. was recipient of a fellowship from the Ministère de l'Enseignement et de la Recherche Scientifique.

Reprints: Dr. N. Vergnolle, Department of Pharmacology and Therapeutics, 3330 Hospital Drive NW, Calgary, Alberta, Canada, T2N4N1 (e-mail: nvergnol@ucalgary.ca).

Copyright (C) 2004 by Lippincott Williams \& Wilkins gested to mediate part of the anti-inflammatory actions of glucocorticoids. ${ }^{2,3}$ Several arguments favor such a physiological role. First, annexin 1 was shown to be physiologically secreted. $^{4-8}$ Second, annexin 1 expression and secretion are induced by glucocorticoids in certain cells or tissues including cells of the macrophage lineage, which are involved in inflammatory processes. ${ }^{1,7,9-15}$ Third, annexin 1 has extracellular anti-inflammatory properties reproducing some of the glucocorticoid actions. Indeed, several studies reported that annexin 1 and some of its fragments reduce the inflammatory response, ${ }^{3,16-19}$ the migration of neutrophils and monocytes, ${ }^{20}$ and inhibit the intracellular enzymes nitric oxide-synthase ${ }^{21}$ and cytosolic phospholipase $\mathrm{A}_{2}{ }^{22}$ The latter action leads to a decreased production of arachidonic acid or eicosanoids, ${ }^{23-25}$ platelet-activating factor, ${ }^{25}$ and oxygene-derived free radicals. ${ }^{26}$ Endogenous anti-inflammatory role for annexin 1 has been fully demonstrated by the fact that annexin 1-deficient mice showed increased expression of proinflammatory molecules (cyclooxygenase-2 and cPLA2) and exaggerated inflammatory response associated with a partial or complete resistance to glucocorticoid treatments. ${ }^{27,28}$ Endogenous secretion of annexin 1 could allow such pathophysiological antiinflammatory role. However, little is known about the natural occurence of annexin 1 secretion, more particularly in inflammatory diseases. In humans, annexin 1 secretion has never been directly related to the inflammatory process. In animals, several studies reported that the extend of inflammatory response was increased after a passive immunization with antiannexin 1 antibodies ${ }^{2,3,18,19,27-31}$ suggesting an extracellular anti-inflammatory role of annexin 1. Moreover, annexin 1 secretion was directly identified and was shown to be selectively induced during an experimental inflammation in a model of rat colitis induced by the administration of trinitrobenzenesulfonic acid (TNBS). ${ }^{32}$ However, annexin 1 secretion has not previously been related to chronic inflammatory bowel disease (IBD) in humans, either ulcerative colitis (UC) or Crohn disease (CD). These diseases are characterized by episodes of active inflammation alternating with periods of quiescence. During Crohn disease relapses, an increase in tissular release of prostaglandin $\mathrm{E}_{2}$ has been correlated with a decrease in annexin 1 expression in intestinal inflammatory tissues. ${ }^{33} \mathrm{Al}-$ 
though the release of small quantities of $\mathrm{PGE}_{2}$ at mucosal surfaces has been shown to be protective, ${ }^{34}$ the large presence of prostaglandin $\mathrm{E}_{2}\left(\mathrm{PGE}_{2}\right)$ in tissues from IBD patients is due to the activation of inflammatory cascade and is associated with the severity of inflammation. ${ }^{35}$ The observation that decreased annexin 1 expression is associated with an increased inflammatory state and increase $\mathrm{PGE}_{2}$ release in Crohn disease is in accordance with the suggested extracellular anti-inflammatory role of annexin 1. However, the occurrence and conditions of annexin 1 secretion in IBD have never been investigated.

Our study shows that annexin 1 secretion is selectively induced in inflamed colons during UC relapses.

\section{PATIENTS AND METHODS}

\section{Patients and Study Design for Biopsy Collection}

Colonic biopsies were collected during the colonoscopy of a total of 20 patients ( 9 women, 11 men, with a mean age of $47.4 \pm 19$ years of standard deviation, or SD) that were admitted in the Gastroenterological Unit of Rangueil Hospital (Toulouse, France) from June 1995 to September 1996. Six control patients ( 3 women, 3 men, mean age $66.2 \pm 10$ years) did not show any sign of colonic inflammation. They were subjected to colonoscopic examination to assess the presence of polyps. Fourteen other patients ( 6 women, 8 men, mean age $39.3 \pm 15$ years) were admitted for UC relapses several months or years after the initial diagnosis of the disease. During each examination, 8 colonic biopsies were removed from the normal mucosa of control patients and from the inflammatory mucosa of patients with active UC. For 5 patients having severe active UC, 8 additional biopsies were collected in a healthy area of colon. As soon as they were removed, biopsies were rinsed in saline. Two biopsies were frozen at $-80^{\circ} \mathrm{C}$ for myeloperoxidase (MPO) activity measurements, the other biopsies were directly processed to analyze annexin 1 expression ( 2 biopsies) or annexin 1 secretion $\left(2\right.$ biopsies incubated at $37^{\circ} \mathrm{C}$ and 2 biopsies incubated at $18^{\circ} \mathrm{C}$ ). For each examination, the disease activity of UC was classified as slight, moderate, or severe using the criteria of Truelove and Witts. ${ }^{36}$

Patients followed drug treatment as indicated in Table 1, amino-salycilate was Pentasa from Fering Laboratories (Gentilly, France), local corticosteroids was Colofoam from Norgine Pharma (Paris, France), and oral glucocorticoid was prednisolone (Solupred) from Houdé Laboratories (Puteaux, France).

\section{Patients and Procedures for Intraluminal Colonic Perfusions}

The colons of 18 voluntary patients were perfused to analyze the in situ release of inflammatory mediators. This study was performed in 1993 in the Hepatology and Gastroen- terology unit of Cochin Hospital (Paris, France) as previously described. ${ }^{37}$ Twelve patients ( 3 women, 9 men, mean age 35.8 \pm 14.5 years) suffering from active UC according to Truelove index were included in the study. Six subjects (4 women, 2 men, mean age $41.3 \pm 21.0$ years) had irritable bowel syndrome but had normal colonoscopy and were considered as controls. The perfusion experiments were performed twice for 3 patients and 4 times for 1 patient. Thus, a total of 24 perfusion experiments were performed, 6 on control patients, 6 on patients with slight UC relapses, and 12 on patients with moderate UC relapses. Patients presenting a diagnosis of severe UC were not included because of the constraint of the procedure and the risk of colonic perforation. Subjects were prepared as for routine flexible rectosigmoid endoscopy by an oral purgative (senosides: X-prep) and saline enema. Colonic perfusion was performed with a specially constructed 4-channel device using polyvinyl chloride tubes of $12-\mathrm{mm}$ diameters. A latex balloon was attached to the tip of one tube to be inflated with air to avoid contamination from the oral side of colon.

The procedure started with an endoscopy of the rectum and of the sigmoid with the tubes attached to the endoscope. When the tubes had reached the desired position (sigmoid), the endoscope was withdrawn. Two tubes were kept at this position, one with the inflated balloon, and a second was used to continuously perfused the colonic segment at $3 \mathrm{~mL} / \mathrm{min}$. The two last channels were placed $20-\mathrm{cm}$ distally and simultaneously collected the perfusate solution by gravity. After a 45minute period to reach equilibrium, perfusate solution were collected and pooled at every 20-minute interval from 20 to 120 minutes, depending on the patient. Each perfusate collected during a 20-minute period was considered as a sample. The perfusate solution contained $\mathrm{NaCl} 120 \mathrm{mM}, \mathrm{Na}_{2} \mathrm{HPO}_{4} 2$ $\mathrm{mM}, \mathrm{KCl} 5.4 \mathrm{mM}$, glucose $10 \mathrm{mM}$, mannitol $35 \mathrm{mM}$, human serum albumin $0.25 \%$ (mass/vol) at $\mathrm{pH} 7.2$ and osmolarity 270 $\mathrm{mOsm} / \mathrm{L}$. Polyethyleneglycol $0.2 \%$ (mass/vol) was added as a nonabsorbable marker as well as aprotinine $(100 \mathrm{UI} / \mathrm{mL})$ to inhibit proteolyic activity. All samples were collected on ice and were immediately completed to $2 \mathrm{mM}$ phenylmethyl sulfonyl fluoride (PMSF) at final concentration. Perfusates were aliquoted and stored at $-80^{\circ} \mathrm{C}$ until analysis.

Patients received medications as indicated in Table 2. Salicylate-containing drugs were sulfazalazine or aminosalicylate, and oral glucocorticoids were prednisolone (Cortancyl, Roussel Laboratories, Paris, France) or Solupred (Houdé Laboratories, Puteaux, France). All treatments were stopped 48 hours before the study ( 15 days for 1 patient and 4 days for another). For 10 of the 14 experiments performed to UC patients, perfusion began in the absence of corticoids, then $11.1 \mathrm{mg} / \mathrm{L}$ of glucocorticoids (Bubenoside, Astra Laboratories, Nanterre, France) were dissolved in the perfusate solution and directly administred at $2 \mathrm{mg} / \mathrm{h}$ into the colonic lumen during 1 to 3 of the latest interval periods of 20-minute perfusion. These experiments allowed us to determine the effect of a di- 
TABLE 1. Disease, Examination, and Treatments of Control Patients (a to $f$ ) and Patients with Ulcerative Colitis (1 to 14) Whose Biopsies Were Collected

\begin{tabular}{|c|c|c|c|c|c|c|c|c|}
\hline \multirow[b]{2}{*}{$\begin{array}{c}\text { Origin of } \\
\text { Examination }\end{array}$} & \multirow[b]{2}{*}{ Examination } & \multirow[b]{2}{*}{ Patients } & \multirow[b]{2}{*}{$\begin{array}{l}\text { Beginning } \\
\text { of the } \\
\text { disease }\end{array}$} & \multicolumn{4}{|c|}{ Anti-inflammatory Therapy Before the Examination } & \multirow[b]{2}{*}{$\begin{array}{c}\text { Truelove and } \\
\text { Witts's Classification }\end{array}$} \\
\hline & & & & 5-ASA & $\begin{array}{c}\text { Local } \\
\text { Corticoids }\end{array}$ & $\begin{array}{c}\text { Oral } \\
\text { Corticoids }\end{array}$ & $\begin{array}{c}\text { Duration } \\
\text { of Corticoid } \\
\text { Treatment }\end{array}$ & \\
\hline \multirow[t]{6}{*}{ Polyps } & Coloscopy & a & & & & & & \\
\hline & & $\mathrm{b}$ & & & & & & \\
\hline & & $\mathrm{c}$ & & & & & & \\
\hline & & $\mathrm{d}$ & & & & & & \\
\hline & & $\mathrm{e}$ & & & & & & \\
\hline & & $\mathrm{f}$ & & & & & & \\
\hline \multirow{17}{*}{$\begin{array}{l}\text { Ulcerative } \\
\text { colitis } \\
\text { relapse }\end{array}$} & First & 1 & 1984 & + & $100 \mathrm{mg} / 24 \mathrm{~h}$ & - & 1.5 month & Moderate \\
\hline & coloscopy & 2 & 1988 & - & - & - & & Slight \\
\hline & & 3 & 1979 & - & - & - & & Slight \\
\hline & & 4 & 1994 & + & - & $50 \mathrm{mg} / 24 \mathrm{~h}$ & 1 month & Moderate \\
\hline & & 5 & 1995 & - & - & $50 \mathrm{mg} / 24 \mathrm{~h}$ & 3 months & Moderate \\
\hline & & 6 & 1994 & + & - & - & & Slight \\
\hline & & 7 & 1993 & + & $100 \mathrm{mg} / 24 \mathrm{~h}$ & - & 2.5 month & Moderate \\
\hline & & 8 & 1984 & - & $200 \mathrm{mg} / 24 \mathrm{~h}$ & $80 \mathrm{mg} / 24 \mathrm{~h}$ & 8 months & Moderate \\
\hline & & 9 & 1984 & + & $50 \mathrm{mg} / 24 \mathrm{~h}$ & - & 1 month & Severe \\
\hline & & 10 & 1994 & - & - & - & & Severe \\
\hline & & 11 & 1995 & + & - & - & & Severe \\
\hline & & 12 & 1994 & + & - & - & & Severe \\
\hline & & 13 & 1992 & - & - & - & & Severe \\
\hline & & 14 & & + & - & - & & Severe \\
\hline & Second & 9 & & - & - & - & & Severe \\
\hline & coloscopy & 4 & & + & - & - & & Severe \\
\hline & Colectomy & 3 & & + & $100 \mathrm{mg} / 24 \mathrm{~h}$ & $7.5 \mathrm{mg} / 24 \mathrm{~h}$ & 6 months & Severe \\
\hline
\end{tabular}

rect and short time exposure of inflamed colons to these steroids.

\section{Myeloperoxydase Activity}

Measurement of myeloperoxydase was used to assess the magnitude of tissue granulocyte infiltration. ${ }^{38}$ Tissues were homogenized and the assay was performed according to Bradley et al. ${ }^{38}$ MPO activity was expressed in U/100 mg of proteins, with $1 \mathrm{U}$ hydrolyzing $1 \mu \mathrm{M} \mathrm{H}_{2} \mathrm{O}_{2} / \mathrm{min}$.

\section{Annexin 1 Expression in Biopsies}

Specimens of human colonic biopsies were collected to identify in vivo annexin 1 expression by immunoblotting. Biopsies were immediately homogenized in a lysis buffer as previously described. ${ }^{32}$ Homogenates (freshly isolated tissues) were then equilibrated in electrophoresis sample buffer, boiled for 5 minutes, and stored at $-80^{\circ} \mathrm{C}$.

\section{Annexin 1 Secretion}

Annexin 1 secretion was studied in vitro by incubating fresh specimens of human colonic biopsies in culture medium.
First, collected biopsies were washed three times in phosphatebuffered saline (PBS) containing EGTA (1 mM), and once in PBS alone, to remove any potential extracellular annexin 1 that could have been secreted in vivo and could be bound to cell surface by a calcium-dependent interaction. Thereafter, tissues were incubated in a culture medium (RPMI 1640, Eurobio, Les Ulis, France; complemented to $1 \mathrm{mM}$ glutamine, $0.02 \mathrm{mM}$ EGTA, $20 \mathrm{mM}$ Hepes, $\mathrm{pH} 7.4$ ) either at $37^{\circ} \mathrm{C}$ to allow protein secretion or at $18^{\circ} \mathrm{C}$, a temperature that inhibits physiological secretory mechanisms. Second, samples were adjusted to 2 $\mathrm{mM}$ final EGTA, rapidly cooled at $0^{\circ} \mathrm{C}$, and further incubated for a 15-minute period to solubilize extracellular annexin 1 . Tissues were then separated from supernatants, homogenized in lysis buffer, and equilibrated in electrophoresis sample buffer as described above. Supernatants were centrifuged at $13,000 \mathrm{~g}$ for 20 seconds to eliminate cells or tissue fragments. The proteins contained in supernatants were then precipitated by a 10 -minute incubation on ice with $10 \%$ (mass/vol) final concentration of trichloroacetic acid (TCA) and were sedimented by centrifugation at $13,000 \mathrm{~g}$ for 10 minutes. They were 
TABLE 2. Disease, Examination, and Treatments of Control Patients and Patients with Active Ulcerative Colitis That Were Subjected to Perfusion Experiments

\begin{tabular}{|c|c|c|c|c|c|c|c|}
\hline \multirow[b]{2}{*}{$\begin{array}{l}\text { Origin of the } \\
\text { Examination }\end{array}$} & & \multirow[b]{2}{*}{$\begin{array}{c}\text { Patient } \\
\text { (Perfusion no.) }\end{array}$} & \multirow[b]{2}{*}{$\begin{array}{l}\text { Beginning of } \\
\text { the Disease }\end{array}$} & \multicolumn{3}{|c|}{$\begin{array}{l}\text { Anti-inflammatory Treatment } \\
\text { Before the Examination }\end{array}$} & \multirow{2}{*}{$\begin{array}{c}\text { Truelove and } \\
\text { Witt's } \\
\text { Classification }\end{array}$} \\
\hline & & & & 5-ASA & $\begin{array}{c}\text { Local } \\
\text { Corticoids }\end{array}$ & $\begin{array}{l}\text { Oral } \\
\text { Corticoids }\end{array}$ & \\
\hline \multirow{6}{*}{$\begin{array}{l}\text { Controls: } \\
\text { Inflammtory } \\
\text { bowel } \\
\text { Syndrome }\end{array}$} & & $\mathrm{s}$ & & - & - & - & \\
\hline & & $\mathrm{t}$ & & - & - & - & \\
\hline & & $\mathrm{u}$ & & - & - & - & \\
\hline & & $\mathrm{u}$ & & - & - & - & \\
\hline & & $\mathrm{w}$ & & - & - & - & \\
\hline & & $\mathrm{x}$ & & - & - & - & \\
\hline \multirow{14}{*}{$\begin{array}{l}\text { Ulcerative } \\
\text { colitis }\end{array}$} & Patients & $\mathrm{n}$ & 1992 & + & - & $25 \mathrm{mg} / 24 \mathrm{~h}$ & Slight \\
\hline & subjected to & $\mathrm{p}$ & 1991 & + & - & - & Slight \\
\hline & 1 perfusion & $\mathrm{r}$ & 1992 & + & - & - & Slight \\
\hline & experiment & $\mathrm{a}$ & 1990 & + & - & - & Moderate \\
\hline & & $\mathrm{i}$ & 1993 & + & - & - & Moderate \\
\hline & & $\mathrm{e}$ & 1992 & + & - & $60 \mathrm{mg} / 24 \mathrm{~h}$ & Moderate \\
\hline & & $\mathrm{f}$ & 1992 & + & - & - & Moderate \\
\hline & & $\mathrm{h}$ & 1993 & - & - & - & Moderate \\
\hline & Patients & $(1 \mathrm{st}) \mathrm{c}$ & 1982 & + & - & $20 \mathrm{mg} / 24 \mathrm{~h}$ & Moderate \\
\hline & subjected to & (2nd) b & & + & - & $45 \mathrm{mg} / 24 \mathrm{~h}$ & Moderate \\
\hline & 2 perfusion & $(1 \mathrm{st}) \mathrm{q}$ & 1992 & + & - & $45 \mathrm{mg} / 24 \mathrm{~h}$ & Slight \\
\hline & experiments & (2nd) j & & + & - & $20 \mathrm{mg} / 24 \mathrm{~h}$ & Moderate \\
\hline & & $(1 \mathrm{st}) \mathrm{d}$ & 1981 & + & - & $50 \mathrm{mg} / 24 \mathrm{~h}$ & Moderate \\
\hline & & (2nd) $g$ & & + & $50 \mathrm{mg} / 24 \mathrm{~h}$ & - & Moderate \\
\hline
\end{tabular}

then resuspended in electrophoresis sample buffer, boiled for 5 minutes, and stored at $-80^{\circ} \mathrm{C}$. For all the experiments of secretion, cell viability was determined by spectrophotometric measurements of lactate dehydrogenase activity in tissue homogenates and supernatants. ${ }^{32}$ The percentage of release of lactacte dehydrogenase (an intracellular enzyme) to the supernatant is equal to the percentage of cell lysis. All tissues displayed low levels of cell lysis (less than 6\%).

\section{Annexin 1 Expression in Intraluminal Perfusates}

Intraluminal perfusates were completed to a final concentration of $1 \mu \mathrm{g} / \mathrm{mL}$ leupeptin, $2 \mu \mathrm{g} / \mathrm{mL}$ aprotinin, $1 \mu \mathrm{g} / \mathrm{mL}$ pepstatin, $1 \mu \mathrm{g} / \mathrm{mL}$ antipain, $15 \mu \mathrm{g} / \mathrm{mL}$ benzamidine, $4 \mathrm{mM}$ PMSF to prevent proteolysis, and $2.5 \mathrm{mM}$ EDTA to solubilize annexin 1. One volume of samples was incubated with 4 volumes of Affi-blue gel (Bio-Rad, Ivry/Seine, France) and 1.5 volumes of $10 \mathrm{mM} \mathrm{KH}_{2} \mathrm{P0}_{4}, 150 \mathrm{mM} \mathrm{NaCl}, \mathrm{pH}$ 7.25. This incubation was performed to clarify samples from the high amount of albumin they contained, to improve annexin 1 detection by immunoblotting. After a 1-hour period of incubation with gentle agitation at $0^{\circ} \mathrm{C}$, samples were centrifuged and su- pernatants were collected. Proteins of the first half of these supernatants were precipitated with $10 \%$ final concentration of TCA as previously described and resuspended in 0.2 volumes of SB. The other half was directly store at $-80^{\circ} \mathrm{C}$ to be subjected to annexin 1 quantification by slot-blot analysis.

\section{Electrophoresis, Immunoblotting, and Quantification}

Sample equilibrated in SB were electrophoretically separated in $10 \%$ polyacrylamide SDS-gels and proteins were transferred onto nitrocellulose. ${ }^{32}$ Annexin 1 was detected by Western blot as previously described, ${ }^{32}$ using a polyclonal antibody raised in the laboratory. Annexin 1 was quantified by slot-blot using different dilutions of each sample and pure human annexin 1 (a gift from F. Russo-Marie, INSERM, Paris, France). Proteins were loaded on nitrocellulose shits using a Bio-Dot SF microfiltration apparatus (Bio-Rad, Ivry sur Seine, France). Annexin 1 was detected by immunoblotting as described above except that for all incubations, tris buffered saline tween (TBST) was supplemented to $10 \%$ (vol/vol) fetal calf serum. Quantification was performed by a densitometric scanning of the fluorographs with a Omni Media Scanner XRS 
12cx (Bioimage, Roissy, France). A linear correlation between densitometric values and the amount of pure annexin 1 was observed for 20 to $100 \mathrm{ng}$ of the loaded protein.

\section{Statistics}

Considering the few values of MPO activity obtained, statistical analysis was performed using a Mann-Whitney test for unpaired data. The criterion for statistical significance was $P<0.05$.

\section{Ethical Considerations}

All patients gave an informed consent for all procedures, which were approved by the Ethical Committee of the Cochin Hospital and the Committee of the Rangueil Hospital.

\section{RESULTS}

\section{Disease Activity and Inflammatory State in Patients for the Colonic Biopsy Study}

Table 1 summarizes the characteristics of UC patients concerning the initial diagnosis of the disease, the medical treatment prescribed for at least 1 month before the study, and the disease activity. During the first coloscopic examination, 6 patients suffered from severe UC and 8 patients from slight or moderate UC symptoms. Patient 9 underwent two coloscopic examinations within 15 months and presented severe UC in both cases. Patient 4 had a moderate UC at the first colonoscopy and a severe UC at the second colonoscopy, 4 months later. Patient 3 presented slight UC activity during the first colonoscopy and, 6 months later, underwent a colectomy for severe UC symptoms.

MPO activity of biopsies was not measured for all the examined patients. Compared with control patients, MPO activities of the inflammatory biopsies were significantly increased in patients with either slight UC $(P=0.039)$, moderate $\mathrm{UC}(P=0.020)$, or severe UC $(P=0.006)$ (Fig. 1$)$. The increase of MPO activities was directly related to disease activity. For patients having severe UC, MPO activity in biopsies from healthy colon was not significantly different from MPO activity of control patients $(P=0.606)$, but was significantly lower $(P=0.036)$ than that of biopsies from inflamed area.

\section{Annexin 1 Expression and Secretion by Colonic Biopsies}

As observed by immunoblotting (Fig. 2), total expression of annexin 1 in colonic biopsies did not present major variations between tissues from control patients and from patients with slight, moderate, or severe UC. Most of the biopsies exclusively contained the native form of the protein $(38 \mathrm{kDa})$. However, biopsies collected from an inflamed area of 6 patients with severe UC were expressing the 2 forms of annexin 1 ( 33 and $38 \mathrm{kDa}$ ). The same specimen expressing the 2 forms

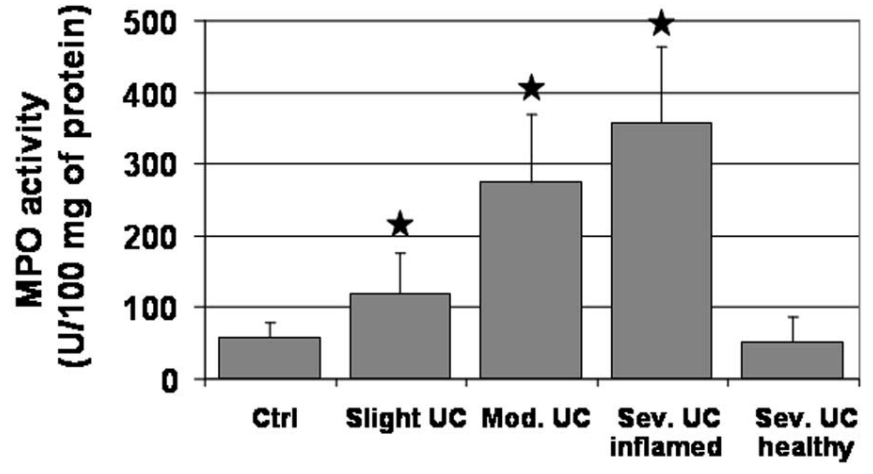

FIGURE 1. Histogram representation of MPO activity (mean \pm SD) in colonic biopsies collected in control patients (ctrl), in pathologic area of patients having UC relapse either slight (Slight UC), moderate (Mod UC), or severe (Sev UC inflamed) or in healthy area of severe UC patients (Sev UC healthy). Individual values of MPO activity are added over the histogram as black squares or triangles. $\mathrm{n}=$ number of samples tested; *values significantly different $(P<0.05)$ than those of control patients.

of annexin 1 also showed the largest MPO activity, thereby having a large number of infiltrated granulocytes.

No major difference was observed in the overall expression of annexin 1 in biopsies from patients treated with glucocorticoids compared with biopsies from other patients.

All biopsies collected in inflamed colonic area from patients having severe $\mathrm{UC}(\mathrm{n}=9)$ released annexin 1 in culture
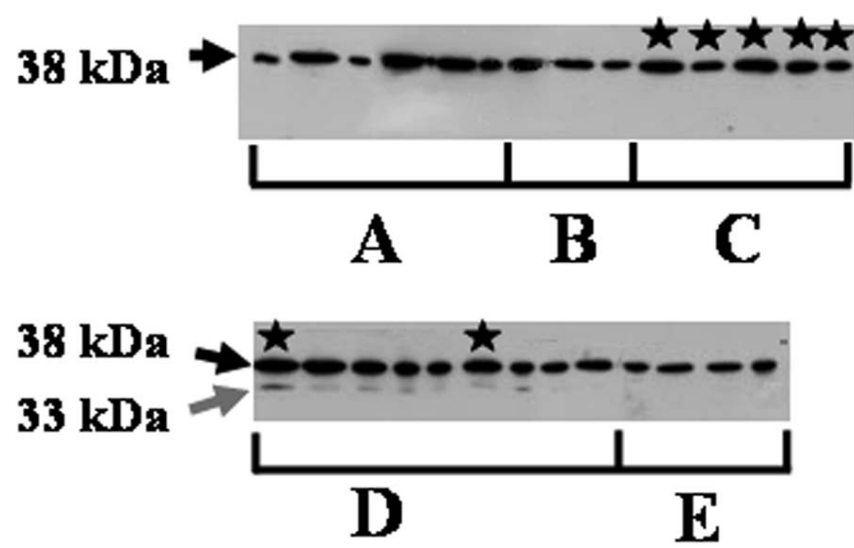

FIGURE 2. Immunologic analysis of human colonic expression of annexin 1 in biopsies from control patients (A), in biopsies collected in pathologic area of patients with slight UC (B), moderate UC (C), or severe UC (D) and in biopsies collected in healthy area from patient with severe UC (E). Annexin 1 was detected in homogenates of freshly isolated biopsies. Equivalent amount of proteins was loaded for each sample. Asterisk ${ }^{*}$ ) represents samples of patients under glucocorticoid therapy. The black arrows show the migration of native annexin 1 and the gray arrow shows the migration of the $33-\mathrm{kDa}$ fragment of annexin 1. 
media when incubated at $37^{\circ} \mathrm{C}$ but not when incubated at $18^{\circ} \mathrm{C}$ (Fig. 3). The 2 forms of annexin 1 (38 and $33 \mathrm{kDa}$ ) were detected in the supernatant of biopsies from patients with severe UC. In contrast, annexin 1 was never detected in the supernatant of biopsies from control patients or from patients with slight or moderate UC, when tissues were incubated either at 37 or $18^{\circ} \mathrm{C}$. Likewise, annexin 1 was not detected in supernatants of biopsies from healthy colon of patients with severe UC. No difference in the occurence of annexin 1 secretion was observed due to the fact patients were treated with glucocorticoids.

\section{Annexin 1 Release in Perfusates}

The disease characteristics of UC patients subjected to perfusion experiments are summarized in Table 2. Figure 4 shows the detection of annexin 1 by immunoblotting in colonic perfusates of controls and patients with active UC (1 sample per perfusion experiment was shown). Annexin 1 was detected in all perfusates from 8 patients over 12 having moderate $\mathrm{UC}$ with a total amount of $7.06 \pm 6.3 \mu \mathrm{g}$ (mean $\pm \mathrm{SD}$ ) of annexin 1 released per minute of perfusion $(n=35$ samples from 8 perfusion experiments). Detailed mean values for annexin 1 quantification are reported in Figure 5. Patients were attributed letters from a to $\mathrm{x}$ to be identified and compared in Figures 4 and 5. All perfusates of 2 patients out of 6 with slight UC symptoms contained annexin 1 with $2.65 \pm 2.75 \mu \mathrm{g} / \mathrm{min}$ of perfusion

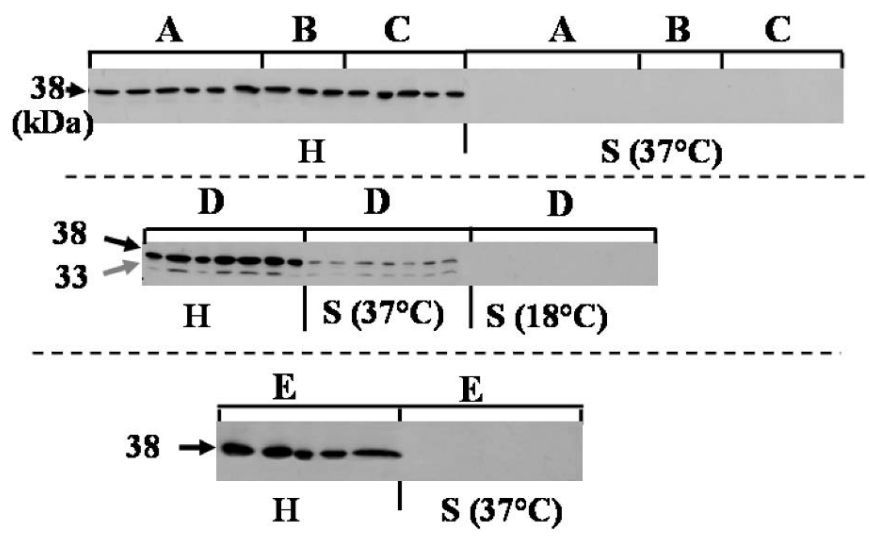

FIGURE 3. Immunoblotting analysis of annexin 1 secretion from human colonic biopsies incubated in medium. Biopsies originated from control patients (A), from a pathologic area of colon from patients having slight $(B)$, moderate $(C)$, or severe (D) UC, or from a healthy area of colon from patients having severe UC (E). Annexin 1 was detected in tissue homogenates $(\mathrm{H})$ and supernatants $(\mathrm{S})$. The 30 -minute period of incubation occurred either at $37^{\circ} \mathrm{C}$ or $18^{\circ} \mathrm{C}$ as mentioned. Equivalent amounts of homogenate proteins were loaded. Supernatant samples were 5 times more concentrated than their corresponding homogenates. The black arrows show the migration of native annexin 1 and the gray arrow shows the migration of the 33-kDa fragment of annexin 1.

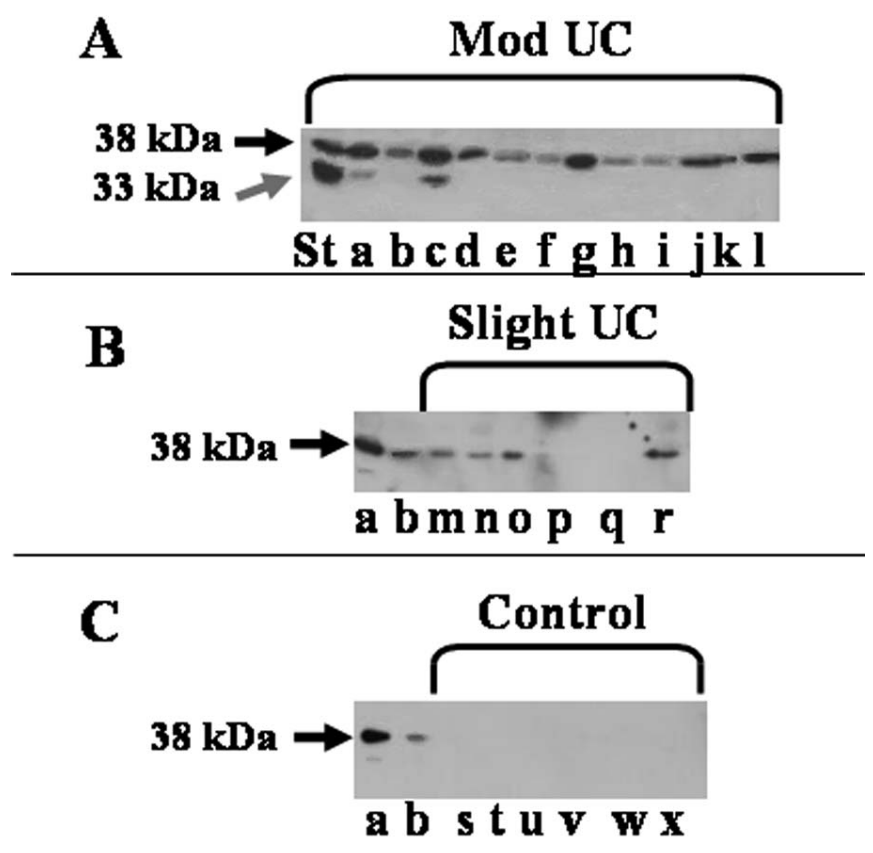

FIGURE 4. Immunoblotting detection of annexin 1 released in colonic perfusates. Perfusates originated from (A) 12 patients (a to I) with moderate UC (Mod UC), (B) 6 patients ( $m$ to $r$ ) with slight UC, or $(C) 6(s$ to $x$ ) control patients. Equivalent protein amount from each perfusate was loaded. A positive control of human annexin 1 (St: standard) was loaded in (A). The black arrows show the migration of native annexin 1 and the gray arrows shows the 33-kDa fragment of annexin 1. Samples $b$ and $c$ are perfusates from patients with moderate UC. They were added in all blots $(A, B$, and $C)$ as internal standard for similar signal intensity during immunoblottings.

( $\mathrm{n}=10$ samples). Annexin 1 was detected in only 1 perfusate from 4 patients having moderate $\mathrm{UC}$ and 2 patients having slight UC (Fig. 4, patients e, f, h, i, m, n). In contrast, annexin 1 was never detected in perfusates from the 2 remaining patients with slight UC or from control patients.

\section{Modulation by Glucocorticoids of Annexin 1 Release in Perfusates}

These experiments were performed on $8 \mathrm{UC}$ patients. Perfusions began without treatment and were followed by the addition of $2 \mathrm{mg} / \mathrm{h}$ of glucocorticoids in the perfused solution. Perfusion samples of 3 patients did not show any detectable amount of annexin 1 either before or during glucocorticoid treatment (not shown). The samples of 2 other patients expressed annexin 1 at similar levels before or during glucocorticoid administration (Fig. 6A). For another patient, no annexin 1 was detected before glucocorticoid treatment, but after the first 20-minute period of glucocorticoid treatment perfusates contained high amounts of annexin 1 (10 $\mu \mathrm{g} / \mathrm{min}$.) (Fig. 6D). Surprisingly, the protein was not any more detected in the perfusate from the following 20-minute perfusion. Two other 


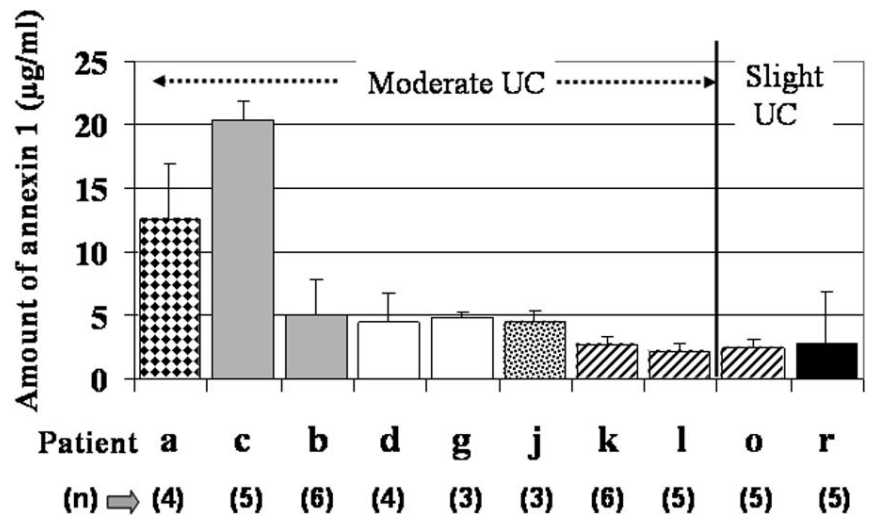

FIGURE 5. Annexin 1 quantification in perfusates from patients with moderate or slight UC. Bars with identical pattern represent perfusates from the same patient but different perfusion experiments. Patient or perfusate numbers are reported below the bars as well as the number ( $n$ ) of perfusate samples tested per perfusion experiment.

patients released annexin 1 in their perfusates with slight increases in annexin 1 levels (1.4- and 2-fold when compared with perfusates without steroids (Figs. 6B and 6C). Interestingly, for one of them, the increase was delayed to the second 20-minute period of glucocorticoid treatment (Fig. 6B).

\section{DISCUSSION}

In this study, the occurence of annexin 1 secretion in human inflammatory bowel disease was investigated to determine whether the protein could be a natural endogenous modulator of the inflammatory response. Our results establish that

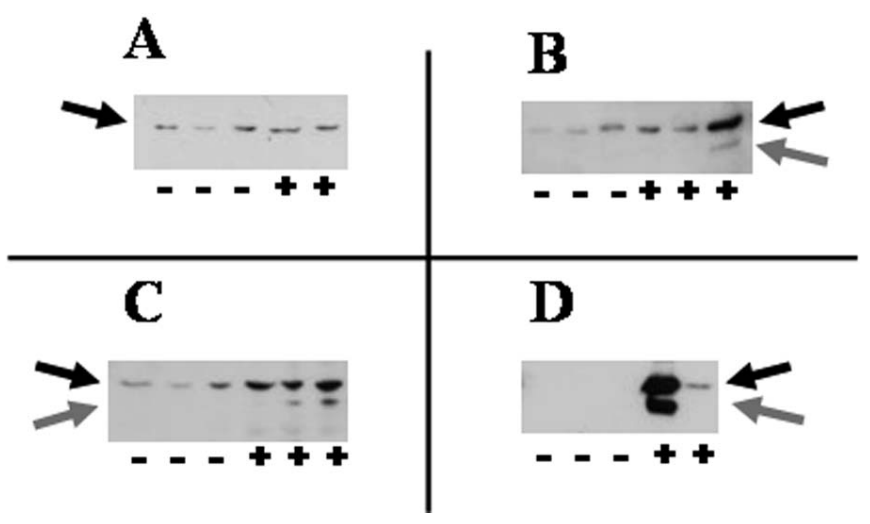

FIGURE 6. Immunoblotting detection of annexin 1 released in perfusates during glucocorticoid treatment in 4 different perfusion experiments (A, B, C, and D). The black arrows show the migration of native annexin 1 and the gray arrows the migration of the 33-kDa fragment of annexin 1. Perfusion were performed in the absence $(-)$ or the presence $(+)$ of glucocorticoids in the perfused solution. Equivalent sample amount of each perfusate was loaded. annexin 1 is specifically secreted by inflamed colons during active UC.

Annexin 1 is released in the culture media of incubated biopsies from UC patients having a severe relapse of the disease. Because annexin 1 lacks secretory signal peptide, its secretion as a physiological process has been questioned. However, the abundance of annexin 1 release in human seminal fluids and in stimulated rat peritoneal macrophages demonstrate a genuine secretion of the protein that seems restricted to particular physiological circumstances. ${ }^{4,7}$ In our experiments, annexin 1 was released from biopsies incubated at $37^{\circ} \mathrm{C}$ but not at $18^{\circ} \mathrm{C}$, a temperature where membrane movements are stopped, showing that this release was a physiological and active process. A similar inhibition has previously been reported for IL1- $\beta$ secretion, suggesting that both proteins are released by a similar secretory pathway. ${ }^{5-8,32,39}$ More importantly, we have established with the current study a link between annexin 1 secretion and pathophysiological circumstances in humans, showing that annexin 1 was specifically secreted by tissues from patients having severe UC relapse. Although annexin 1 secretion was reported in hypothalamus and pituitary glands, ${ }^{14}$ in human seminal fluids, and in human bronchoalveolar lavages, ${ }^{11,32,41-43}$ none of these studies have established a link between annexin 1 secretion and human inflammatory disease. Our study clearly relates annexin 1 secretion to inflammatory bowel disease, and more particularly to the severity of IBD relapse.

Two forms of annexin 1 (33 and $38 \mathrm{kDa}$ ) were released in culture media from colonic biopsies of human severe UC patients. We have previously shown that the production of the $33-\mathrm{kDa}$ annexin 1 by proteolysis of the native protein of 38 $\mathrm{kDa}$ occurs in the extracellular space. ${ }^{31}$ Indeed, this fragment can be completely extracted from tissues by washing them in the presence of 1-2 mM EGTA (Ref. 32 and Fig. 3 in this study). It appears then that native annexin 1 can be secreted, and part of it might be cleaved by extracellular proteases. Because most of the tissues secreting annexin 1 in vitro also contained the 2 forms of the protein in homogenates of freshly isolated biopsies, this suggests that annexin 1 secretion also occurred in vivo. This in vivo secretion of annexin 1 was further confirmed by perfusion experiments, which showed the release of annexin 1 in colonic perfusates of patients suffering from active UC.

Annexin 1 was secreted by all biopsies collected from the inflamed colon of severe UC patients but not by biopsies from healthy area of the same colon. The nonpathologic diagnosis of these latter area issued from endoscopic examination was confirmed by measurement of MPO activity that was not significantly different from control patients. This shows that in humans, annexin 1 secretion in colons is specifically related to inflammation. In accordance with these results, the secretion of colonic annexin 1 was never detected in biopsies or in perfusates from control patients. The levels of annexin 1 in per- 
fusates reached the range of $\mu \mathrm{g} / \mathrm{min}$ of perfusion, which is more than 1000-fold higher than the levels of cytokines (tumor necrosis factor, IL1- $\beta$, IL-6, and IL-8) previously quantified in the same samples. Considering that only part of the total secreted annexin 1 has been released into the perfusates because of the absence of calcium chelators in the perfusion buffer, annexin 1 appears to be extremely abundant in the colon of UC relapse patients. These results, which again suggest a major role for annexin 1 in IBD, are in accordance with the correlation of IBD activity with the presence of auto-antibodies against annexin $1 .{ }^{39}$

Only biopsies from patients with severe UC secrete annexin 1 , whereas some colons of patients having moderate or slight UC release the protein in perfusates. This can be explained by differences in the procedures. Annexin 1 release from small tissue fragments as biopsies $(10 \mathrm{mg})$ could be more difficult to detect than annexin 1 released from a whole $20-\mathrm{cm}$ portion of colon. This study shows that perfusion experiments were more discriminatory than secretion experiments on biopsies to detect annexin 1 secretion.

Several studies have reported that annexin 1 secretion is induced by glucocorticoids during healthy or pathologic conditions. In healthy conditions, glucocorticoids increase annexin 1 secretion in hypothalamus, in quiescent rat peritoneal macrophages, in human peripheral blood leukocytes, in rat skin, or in bronchoalveolar fluids. ${ }^{7,9,11-15,20,24,40,45}$ During inflammation in rodents, the presence of a systemic secretion of annexin 1 in blood is induced by glucocorticoids in an airpouch model and in zymosan-induced peritonitis. ${ }^{29,30}$ However, characterizing TNBS-induced colitis in rats, we showed that colonic expression and secretion of annexin 1 were regulated independently of the presence of glucocorticoids. ${ }^{45}$ In the current study, we did not observe differences in the occurence of annexin 1 secretion in human UC colons, whether or not the patients have been treated with glucocorticoids (Fig. 3). Together with the TNBS-induced colitis study, ${ }^{45}$ the current results suggest that in situ secretion of annexin 1 during intestinal inflammation is regulated by one or several agents other than glucocorticoids. Solito et $\mathrm{al}^{47}$ showed that in the epithelial cell line A 549, annexin 1 transcription was stimulated by glucocorticoids, phorbol myristate acetate, with a synergistic effect of both agents in a promoter region bearing the responsive element of nuclear factor for interleukin 6 expression (NF-IL6). The same authors showed that IL-6, dexamethasone, and to a greater extent IL-6 plus dexamethasone increased annexin 1 gene transcription as well as protein neosynthesis and secretion. ${ }^{48}$ Another study on rat $\alpha 1$-acid-glycoprotein showed that glucocorticoid receptor and NF-IL6 synergistically activate the gene transcription by a direct protein-protein interaction. ${ }^{47}$ Similar cooperation of these two transcription factors might regulate annexin 1 expression and secretion in the colon of UC patients. Perfusion experiments showed that in 3 patients out of 8 , annexin 1 secretion was induced by a short-term treat- ment with glucocorticoids (Fig. 6B). The observed discrepancy between subjects, concerning the effects of glucocorticoids to induced annexin 1 release in perfusates of UC patients, could be then related to the overall in vivo expression of several transcription factors in inflamed colon.

In conclusion, our study suggests that annexin 1 plays an active role during UC, as it is largely secreted in vivo, specifically by inflamed colons, and thus can exert its antiinflammatory properties. Another important point of this study is the observation that annexin 1 secretion might be dependent on the stage of cell activation in the inflammatory site but also certainly of the severity of the relapse. Finally, this study showed that annexin 1 expression and secretion in human inflammatory colons are largely independent of glucocorticoid medication, even though in some cases a short-term glucocorticoid treatment can participate to the induction of annexin 1 secretion.

\section{REFERENCES}

1. Gerke V. SE. Annexins: from structure to function. Physiol Rev. 2002;82: 331-371.

2. Goulding NJ, Guyre PM. Glucocorticoids, lipocortins and the immune response. Curr Opin Immunol. 1993;5:108-113.

3. Flower RJ, Rothwell NJ. Lipocortin-1: cellular mechanisms and clinical relevance. Trends Pharmacol Sci. 1994;15:71-76.

4. Christmas P, Callaway J, Fallon J, et al. Selective secretion of annexin 1, a protein without a signal sequence, by the human prostate. $J$ Biol Chem. 1991;266:2499-2507.

5. Serres M, Coméra C. Schmitt D Annexin 1 regulation in human epidermal cells. Cell Mol Biol. 1994;40:701-706.

6. Rubartelli A, Bajetto A, Bonifaci N, et al. A novel way to get out of the cell. Cytotechnology. 1993;11(suppl 1):S37-S40.

7. Coméra C, Russo-Marie F. Glucocorticoid-induced annexin 1 secretion. Br J Pharmacol. 1995;115:1043-1047.

8. Philip JG, Flower RJ, Buckingham JC. Blockade of the classical pathway of protein secretion does not affect the cellular exportation of lipocortin 1 . Regul Pept. 1998;73:133-139.

9. Goulding NJ. Godolphin JL, Sharland PR, Peers SH, Sampson M, Maddison PJ, Flower RJ. Anti-inflammatory lipocortin 1 production by peripheral blood leucocytes in response to hydrocortisone. Lancet. 1990; 335:1416-1418.

10. Solito E, Raugei G, Melli M, et al. Dexamethasone induces the expression of the mRNA of lipocortin 1 and 2 and the release of lipocortin 1 and 5 in differenciated but not in undifferenciated U-937 cells. FEBS Lett. 1991; 291:238-244.

11. Ambrose MP, Bahns CC, Hunninghake GW. Lipocortin I production by human alveolar macrophages. Am J Respir Cell Mol Biol. 1992;6:17-21.

12. Peers SH, Smillie F, Elderfield AJ, et al. Glucocorticoid-and nonglucocorticoid induction of lipocortins(annexins) 1 and 2 in rat peritoneal leucocytes in vivo. Br J Pharmacol. 1993;108:66-72.

13. Perretti M, Flower RJ. Measurement of glucocorticoids levels in murine peripheral blood leucocytes by flow cytometry : modulation by glucocorticoids and inflammation. Br J Pharmacol. 1996;118:605-610.

14. Buckingam JC, Flower RJ. Lipocortin 1 : a second messenger of glucocorticoid action in the hypothalamo-pituitary-adrenocortical axis. Mol Med Today. 1998;3:296-302.

15. Mizuno H, Asai K, Fujita K, et al. Neurotrophic action of lipocortin 1 derived from astrocytes on cultured rat cortical neurons. Brain Res Mol Brain Res. 1998;60:28-39.

16. Cirino G, Peers SH, Flower RJ, et al. Human recombinant lipocortin 1 has acute local anti-inflammatory properties in the rat paw oedema test. Proc Natl Acad Sci USA. 1989;86:3428-3432.

17. Cirino G, Cicala C, Sorrentino L, et al. Anti-inflammatyory actions of a 
N-terminal peptide from human lipocortin 1. Br J Pharmacol. 1993;108: 573-574.

18. Yang Y, Leech M, Hutchinson P, et al. Antiinflammatory effect of lipocortin 1 in experimental arthritis. Inflammation. 1997;21:583-596.

19. Huitinga I, Bauer J, Strijbos PJ, et al.. Effect of annexin-1 in experimental autoimmune encephalomyetis (EAE) in the rat. Clin Exp Immunol. 1998; 111:198-204.

20. Perretti M. Endogenous mediators that inhibits the leukocyte-endothelium interaction. Trends Pharmacol Sci. 1997;18:418-425.

21. Wu CC, Croxtall JD, Perretti M, et al. Lipocortin 1 mediates the inhibition by dexamethasone of the induction by endotoxin of nitric oxide synthase in the rat. Proc Natl Acad Sci USA. 1995;92:3473-3477.

22. Croxtall JD, Choudhury Q, Newman S, et al. Lipocortin 1 and the control of cPLA2 activity in A549 cells. Glucocorticoids block EGF stimulation of cPLA2 phosphorylation. Biochem Pharmacol. 1996;52:351-356.

23. Cirino G, Flower RJ, Browning JL, et al. Recombinant human lipocortin I inhibits thromboxane release from guinea-pig isolated perfused lung. Nature. 1987;328:270-272.

24. Sudlow AW, Carey F, Forder R, et al. The role of lipocortin-1 in dexamethasone-induced suppression of PGE2 and TNF $\alpha$ release from human peripheral blood mononuclear cells. Br J Pharmacol. 1996;117:14491456.

25. Fradin A, Rothhut B, Poincelot-Canton B, et al. Inhibition of eicosanoid and PAF formation by dexamethasone in rat inflammatory polymorphonuclear neutrophils may implicate lipocortin's. Biochim Biophys Acta. 1988;963:248-257.

26. Maridonneau-Parini I, Errasfa M, Russo-Marie F. Inhibition of $\mathrm{O}_{2}^{-}$generation by dexamethasone is mimicked by lipocortin 1 in alveolar macrophages. J Clin Invest. 1989;83:1936-1940.

27. Roviezzo F, Getting SJ, Paul-Clark MJ, et al. The annexin-1 knockout mouse: what it tells us about the inflammatory response. J Physiol Pharmacol. 2002;53:541-553.

28. Becherucci C, Perretti M, Solito E, et al. Conceivable difference in the anti-inflammatory mechanisms of lipocortin 1 and 5. Mediators Inflamm. 1993;2:109-113.

29. Perretti M, Flower RJ. Modulation of IL-1 induced neutrophil migration by dexamethasone and lipocortin I. J Immunol. 1993;150:992-999.

30. Getting SJ, Flower RJ, Perretti M. Inhibition of neutrophil and monocyte recruitment by endogenous and exogenous lipocortin 1. Br J Pharmacol. 1997;120:1075-1082.

31. Relton JK, Strijbos PJLM, O'Shaughnessy CT, et al. Lipocortin-I is an endogenous inhibitor of ischaemic brain damage in the rat brain. $J$ Exp Med. 1991;174:305-310.

32. Vergnolle N, Comera C, Bueno L. Annexin 1 is overexpressed and specifically secreted during experimentally induced colitis in rats. Eur J Biochem. 1995;232:603-610.
33. Sakanoue $\mathrm{Y}$, Horai T, Okamato T, et al. Lipocortin-present perforating and lipocortin-absent nonperforating Crohn's disease. Am J Surg. 1992; 164:341-344.

34. Johansson C, Bergstrom S. Prostaglandin and protection of the gastroduodenal mucosa. Scand J Gastroenterol. 1982;77:21-46.

35. Hawkey CJ, Karmeli F, Rachmilewitz D. Imbalance of prostacyclin and thromboxane synthesis in Crohn's disease. Gut. 1983;24:881-885.

36. Truelove SC, Witts LJ. Cortisone in UC. Final report on a therapeutic trial. BMJ. 1955;2:1041-1048.

37. Guimbaud R, Izzo A, Martinolle JP, et al. Intraluminal excretion of PAF, LysoPAF and acetylhydrolase in patients with ulcerative colitis. Dig Dis Sci. 1995:40:2636-2640.

38. Bradley P, Priebat DA, Christensen RD, et al. Measurement of cutaneous inflammation: estimation of neutrophil content with an enzyme marker. $J$ Invest Dermatol. 1982;78:206-209.

39. Rubartelli A, Cozzolino F, Talio M, et al. A novel secretory fragment for interleukin-1 $\beta$, a protein lacking a signal sequence. EMBO J. 1990;9: $1503-1510$.

40. Stevens TR, Smith SF, Rampton DS. Antibodies to human recombinant lipocortin-I in inflammatory bowel disease. Clin Sci (Colch). 1993; 84:381-386.

41. Ambrose MP, Hunninghake GW. Corticosteroids increase lipocortin I in BAL fluid from normal individuals and patients with lung disease. $J$ Appl Physiol. 1990;68:1668-1671.

42. Smith SF, Tetley TD, Datta AK, et al. Lipocortin-1 distribution in bronchoalveolar lavage from healthy human lung: effect of prednisolone. $J$ Appl Physiol. 1995;79:121-128.

43. Jorens PG, Sobille Y, Goulding NJ, et al. Potential role of Clara cell protein, an endogenous phospholipase A2 inhibitor in acute lung injury. Eur Respir J. 1995;8:1647-1653.

44. Ahluwalia A, Mohamed RW, Flower RJ. Induction of lipocortin 1 by topical steroid in rat skin. Biochem Pharmacol. 1994;48:1647-1654.

45. Vergnolle N, Coméra C, Alvinerie M, et al. Local expression and secretion of lipocortin 1 in inflammatory gut are not linked to the activation of the adreno-pituitary axis. Am J Physiol. 1997;273:R623-R629.

46. Solito E, deCoupade C, Parente L, et al. Human annexin 1 is highly expressed during the differentiation of the epithelial cell line A549: Involvement of nuclear factor interleukin 6 in phorbol ester induction of annexin 1. Cell Growth Differ. 1998;9:327-336.

47. Solito E, de Coupade C, Parente L, et al. IL-6 stimulates annexin 1 translocation and suggests a new biological role as class-II acute phase protein. Cytokine. 1998;10:514-521.

48. Nishio Y, Hissiki H, Kishimoto T, et al. A nuclear factor for interleukin-6 expression (NF-IL6) and the glucocorticoid receptor sygernistically activate transcrition of the rat alpha 1-acid glycoprotein gene via direct protein-protein interaction. Mol Cell Biol. 1993;13:1854-1862. 